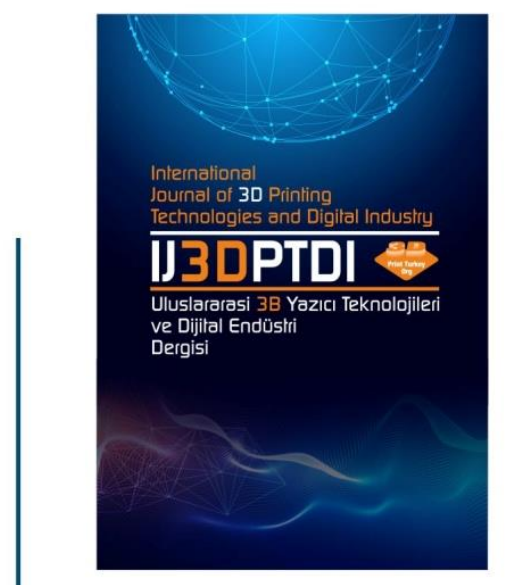

ULUSLARARASI 3B YAZICI TEKNOLOJILERI

VE DIJITAL ENDÜSTRI DERGISI

INTERNATIONAL JOURNAL QF 30 PRINTING TECHNOLOGIES AND DIGITAL INDUSTRY

ISSN:2602-3350 [Online]

URL: https://dergipark.org.tr/ij3dptdi

\title{
TITANIUM IMPLANT FOR DENTAL APPLICATIONS USING 3D PRINTING TECHNOLOGY
}

Yazarlar (Authors): Senai YALCINKAYAa(i), Ebuzer AYGUL ${ }^{b}$ and Yusuf SAHINc (i)

Bu makaleye şu şekilde atıfta bulunabilirsiniz (To cite to this article): Yalcinkaya S., Aygul E., Sahin Y.." Titanium Implant For Dental Applications Using 3d Printing Technology", Int. J. of 3D Printing Tech. Dig. Ind., 4(2): 171-177, (2020).

DOI:

Erişim Linki: (To link to this article): https://dergipark.org.tr/en/pub/ij3dptdi/archive 


\title{
TITANIUM IMPLANT FOR DENTAL APPLICATIONS USING 3D PRINTING TECHNOLOGY
}

\author{
Senai YALCINKAYA ${ }^{a}$ iD*, Ebuzer AYGUL ${ }^{a}$ iD and Yusuf SAHIN ${ }^{\mathrm{b}}$ iD \\ ${ }^{a}$ Marmara University, Technology Faculty, Department of Mechanical Engineering, TURKEY \\ ${ }^{\mathrm{b}}$ Near East University, Engineering Faculty, Department of Mechanical Engineering, TURKEY \\ *Corresponding author: ebuzer.aygul@marmara.edu.tr
}

(Received: 04.08.2020; Revised: 08.08.2020; Accepted: 12.08.2020)

\begin{abstract}
The aim of this study is to provide information about 3D printing techniques and investigate the relationship between 3D printing and titanium implants. Rapid prototyping or 3D Printing is defined as the processes and technologies used to generate physical models from Computer Aided Design (CAD) files through a program. 3D printers are generally used in engineering, architecture, jewelry, Art, medical and dental sectors. Especially in the sectors related to production, there is a great need for 3D printer. 3D printers provide incredible convenience for prototype production. Depending on the development of the technology, it was possible to use titanium material with 3D printers. This study provides a solution for problems related to dental implant devices and materials used in biomedical engineering- medical applications.
\end{abstract}

Keywords: 3D Printing, Titanium Implant, Biomedical Applications.

\section{INTRODUCTION}

In recent years, 3D printing techniques and technologies have improved a lot, and the variety of materials used in these printers has also increased. Increasing material diversity also allowed 3D printers to be used in different areas. 3D printing, also called rapid prototyping, is now used in different applications and sectors [1]. When the researches about 3D printers are examined, it is seen that they are generally used in macro dimensions. However, it is also used in areas related to the micro system [2-11]. Product creation is the primary use of 3D printing technology for today. These machines provide cost-effectively test ideas for dimensional products before they begin expensive mold and manufacturing processes for designers and engineers. 3D printing technology is now readily available in every application [12]. Manufacturing with 3D printer has very important advantages. For example, there is only device or system production from computer designs. Here, time, personnel cost, and scarcity of devices are of great advantage Fabrication systems are usually installed for the production of a device. These systems are quite costly. However, sometimes production facilities can be built with 3D printers at a much lower cost instead of production facilities. An example 3D printer is shown in Figure 1. [13,14]. With 3D printing technology, it might be used to produce simple parts such as automotive, medical, aerospace, consumer goods, toys, and regency items [15]. In recent years, it has been significant that the use of $3 \mathrm{D}$ printing has increased in the medical sector [16]. For instance, it emerges as a fast, affordable, and cost-effective tool for the manufacture of specially designed medical implants [17]. Implants are natural or synthetic materials used to support or support the functions of living tissues in the human body, and they continuously or periodically contact body fluids [18]. Titanium metal, which is known to exhibit high biocompatibility in physical and chemical terms, is significant in terms of being the most widely used implant [19]. 


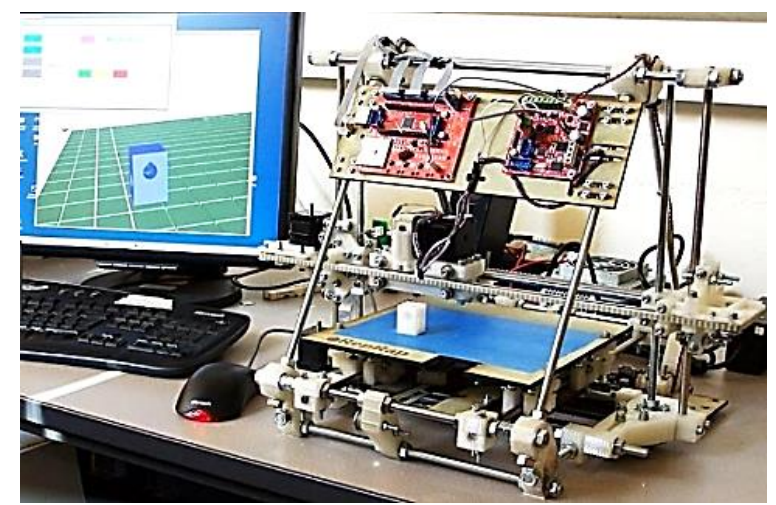

Figure 1. The Schematic of 3D printing [14].

In recent years, a significant increase in the application of titanium to the medical and dental area has been observed with titanium lightness, the tight hexagonal structure at room temperature, suitable corrosion values, self-immobilized oxide layer which prevents active substances. Chemical reaction, proper resonance values due to non-magnetic properties, low allergic properties, and being the best biocompatible metal in long-term implants [20]. Titanium implants have some advantages as well as offers superior features. These are in particular, the unique anatomy of the orbit that is implanted and the resulting surgical approaches are not adequately. In order to overcome the drawbacks of this field, researchers are carrying out serious studies on the modification and development of the implant. An implant type with better modularity and similar features to bone pore cells was introduced by researchers with $3 \mathrm{D}$ printing technology, along with practical examples and content $[21,22]$. This is a layered production technique based on the 3D printer inkjet print deposition concept. List of necessary steps and materials to create a 3D printer in operation 3D printer technology. It is aimed to give details of the features and advantages of 3D implant production with the 3D printer.

\section{DENTAL APPLICATIONS by 3D-PRINTING}

The developments in computer technology and software applications form the basis of today's 3D printing technology. Some requirements are needed to make dental applications with 3D printers. First of all, CAD designs must be made for each application. Then there is a need for scientific data on devices used in medical applications [23, 24]. Figure 2 shows the 3D printing process steps used in biomedical applications in general.

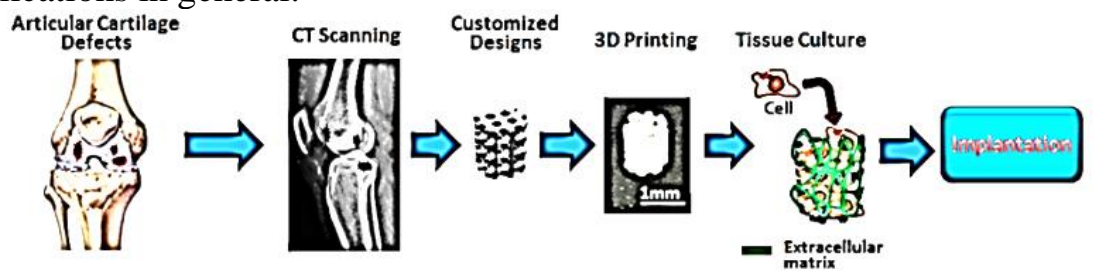

Figure 2. 3D printing process in biomedical applications [24].

3D printing is also called rapid prototyping, computerized automatic production, depending on the fabrication technique used. Rapid prototyping covers many established manufacturing techniques and numerous experimental Technologies that have been developed by small teams. Each method has its limitations and prototype model generation applications [25-27]. Many academic studies have been conducted on 3D printer and titanium powder alloys. These studies were done with Selective Laser Sintering (SLS) and Powder Bed Fusion (PBF) techniques [28-30]. Three-Dimensional Printing (3DP), invented at the Massachusetts Institute of Technology, is based on the ability to produce 3D structures in a powder layer with an ink-jet liquid solvent solution [31-33]. Moreover, although the diagram of the working principles of the other techniques is given in figure 3, the study tribology and shape are not given in detail because it is not the subject of this article. 


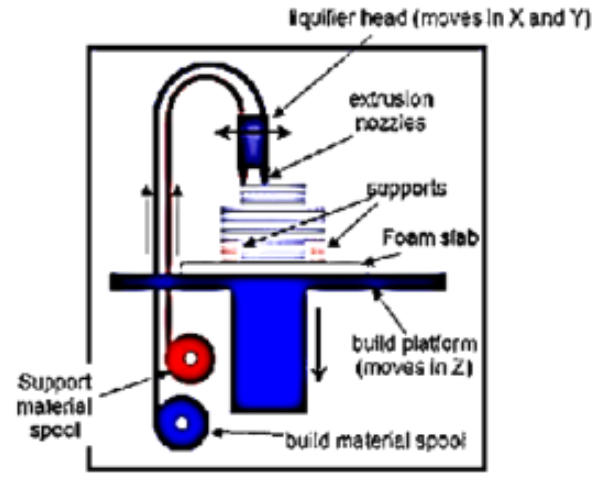

Figure 3A Fused deposition modeling schematic.

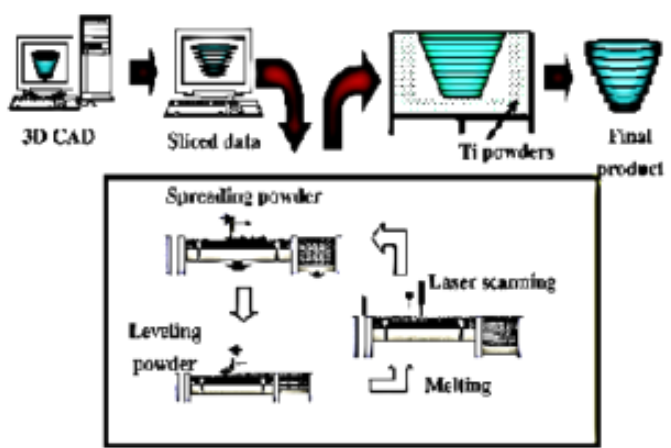

Figure $3 \mathrm{C}$ Selective laser sintering schematic.

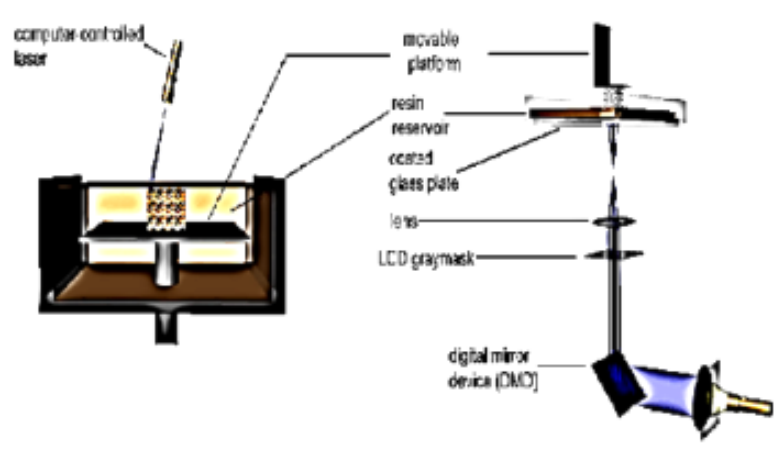

Figure 3B Stereolithography schematic.

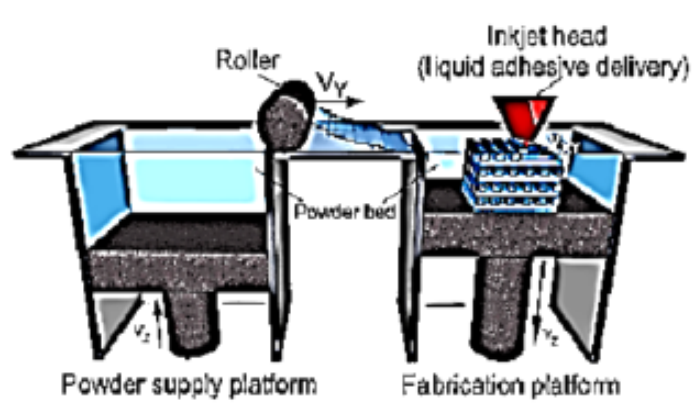

Figure 3D Printing schematic.

Figure 3. 3D Printing schematic [34].

\section{PRINTING OF TITANIUM IMPLANTS}

Titanium and its alloys are widely used in the construction of biomedical, dental implants, mobile and stationary dentures due to their excellent biocompatibility and corrosion resistance, low elasticity values, and high resistance. However, new studies are needed to determine optimum properties and production methods for the use of titanium in fixed and mobile prostheses [35]. The unique surface orbital implant that the implants have directly affected the force and stress sharing between tissue and bone. Force and stress-strain are directly proportional to the elasticity of the material $[36,37]$. They also found that the pores accelerated the formation of the bone around the implant in some cases. Researchers used implant manufacturing methods to obtain porous titanium implants, sintering, 3D printing, additive manufacturing, and similar methods. Since other forms of production are not the subject of this article, this work will briefly be referred to as the 3D printing production model. Modern dental implants consist of three different materials. These materials consist of Zirconia, Alumina and Titanium [38]. Aluminum and Zirconia are widely used for applications that require high strength, and Titanium is also used for applications that require biocompatibility. Table 1 shows the physical properties of the biomaterials [39-41]. 
Table 1. Physical properties of biomaterials. [41].

\begin{tabular}{|c|c|c|}
\hline Material & Strenght (Mpa) & Modulus (GPa) \\
\hline Natural jaw bone & $130-180$ & $3-20$ \\
\hline PIGA & 2.82 & 2 \\
\hline Stainless steel 316L & $170-750$ & 200 \\
\hline Co-Cr-Mo & $275-1585$ & $200-230$ \\
\hline Yttria-stabilized zirconia & $900-1400$ & 210 \\
\hline $\mathrm{Ti}-6 \mathrm{Al}-4 \mathrm{~V}$ & $895-930$ & $110-114$ \\
\hline $\begin{array}{l}\text { Commercially pure } \\
\text { Titanium }\end{array}$ & $240-550$ & $102-105$ \\
\hline Alumina & 400 & 350 \\
\hline
\end{tabular}

Using Engineering through Processing, Pure Titanium can be reduced to conform to the modular bone by providing porosity. It has been reported that porous Titanium has molecular mechanical properties that can help humans to load continuously on the jaw compared to load conditions [42,43]. A 3D printer (3DP) layered production technology based on the inkjet print deposition concept has been promised to meet these requirements. As can be seen from Figure 4, it works as follows:

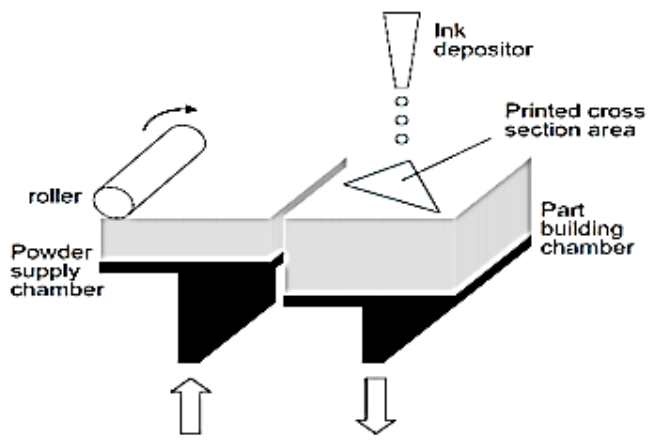

Figure 4. 3D printing process [41].

The implant with titanium material is primarily designed with computer-aided design (CAD). The 3D design made is converted to STL file format. It is then transferred to the 3D printer device for prototype production. All these processes take place quickly in order. This action produces a combined powdered substance layer in selected areas. After that, the workbench chamber is lowered in one-layer thickness after the powder feed chamber is moved upward to provide a new layer of powder layer after printing. These steps are repeated until the track is last created. As the copy is made, the unprinted dust becomes natural support and is finally cleared of the final part [43,44]. An example of a fabricated porous titanium implant is shown in figure 5 .

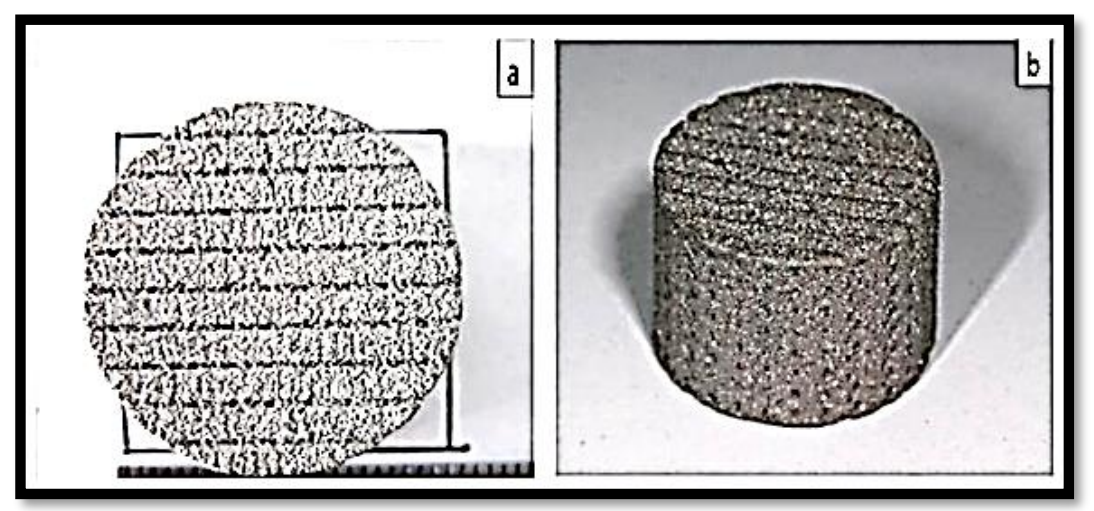

Figure 5. Producted porous Ti (a) Tp view; (b) Front view [41]. 


\section{CONCLUSION}

It is difficult to make customized designs in some applications. Because design sensitivities must be calculated beforehand. Moreover, the applied biocompatible material must have static and dynamic properties compatible with human bone and tissue. Many types of research have been carried out in order to improve the static and dynamic properties of titanium and its alloys, which are a phenomenon in biomedical, dental applications. In this work, the 3D printing given to promote the dynamic and static properties of titanium functions with the repression of a bonding material on each powder layer in order to deposit the powder material repeatedly in the thin layers and to deposit the deposited powder in this layer. This process is repeated from the CAD model to the post-layer layer up to the completion of the whole 3D part according to the sliced data.

As a result of the investigations, it has been shown that this technology can be used in biomedical engineering to solve common problems in dental implant applications. Particularly in dental applications, the phenomenon of mass accumulation of small pores in the dental implant allows the cells to enlarge in the pore implant, as well as an anymore decrease in the module of the bulk titanium material.

\section{REFERENCES}

1. Mishra, M., "3D Printing Technology", Science Horizon, Vol. 43, Issue 11, Pages 15-22, 2014.

2. Ertugrul, I., "The Fabrication of Micro Beam from Photopolymer by Digital Light Processing 3D Printing Technology." Micromachines, Vol. 11, Issue 5, Pages 518-526, 2020.

3. Lifton, V.A., Gregory L., Steve S., "Options for additive rapid prototyping methods (3D printing) in MEMS technology." Rapid Prototyping Journal Vol. 20, Issue 5, Pages 403-412, 2014.

4. Lessing, J., Glavan, A. C., Walker, S. B., Keplinger, C., Lewis, J. A., "Inkjet Printing of conductive inks with high lateral resolution on omniphobic "Rf paper" for paper-based electronics and MEMS." Advanced Materials Vol. 26, Issue 27, Pages 4677-4682, 2014.

5. Ertugrul, I., Ülkir, O., "MEMS Tabanlı Mikro Rezonatörün Tasarımı ve Analizi", Avrupa Bilim ve Teknoloji Dergisi , Vol. 18, Issue 2, Pages 25-29, 2020.

6. Ülkir, O., Ertugrul, I. "Mikro Kiriş Uzunluğu Değişiminin Deformasyona Etkisinin Araştırılması", Avrupa Bilim ve Teknoloji Dergisi , Vol. 18, Issue 2, Pages 136-141, 2020.

7. Ertugrul, I., Akkus, N., Aygul, E., Yalcinkaya, S., Ertunç, H., "MEMS Fabrication using PuSL Technique Based 3D Printer", International Journal of 3D Printing Technologies and Digital Industry, Vol. 4, Issue 1, Pages 38-43, 2020.

8. Jones, H. B., Moore, C. P., Best, A. D., Bubendorfer, A. J., "Rapid prototyping MEMS with laminated resin printing. International Society for Optics and Photonics", In Emerging Digital Micromirror Device Based Systems and Applications XII, Vol. 11294, Issue 5, Pages 1129407-1129413, 2020.

9. Ertugrul, I., Akkus, N., Aygül, E., Yalcinkaya, S. "Mems Fabrication Using 2PP Technique Based 3D Printer". International Journal of 3D Printing Technologies and Digital Industry Vol. 4, Issue 1, Pages $12-17,2020$.

10. Blachowicz, T., Andrea, E., "3D Printed MEMS Technology—Recent Developments and Applications." Micromachines, Vol. 11, Issue 4, Pages 434-441, 2020.

11. Ertugrul, I., Aygul, E., Yalcinkaya, S., Ulkir, O., "Analysis of MEMS Based Accelerometer Sensor via Comsol" 5nd International Congress on Engineering, Architecture and Design, Pages 1-5, Istanbul, 2019

12. Aygul, E., Yalcinkaya, S, Sahin, Y., "Corrosion characterıstıcs of an additıve-manufacturing cobaltchrome-wolfram biomedical alloy under heat-treated and molybdenum-doped conditions." Materiali in tehnologije / Materials and technology Vol. 54, Issue 4, Pages 535-540, 2020 
13. Bogue, R., "3D printing: the dawn of a new era in manufacturing?", Assembly Automation, Vol. 33, Issue 4, Pages 307-311, 2013

14. Campbell, T., Williams, C., Ivanova, O., "Could 3D printing change the world." Technologies, Potential, and Implications of AdditiveManufacturing, AtlanticCouncil, Pages 145-152, Washington DC, 2011.

15. Academic work with 3D printers, https://www.atlasobscura.com/articles/the-utopian-promise-of-reprap-the-3d-printer-that-canalmostprintitself, November 15, 2019

16. Martelli, N., Serrano, C., Brink, H., Pineau, J., Prognon, P., Borget, I., "3D Printing in Medicine”, Scientific Research Publishing, Vol. 13, Issue 1, Pages 157-164, 2016.

17. Schubert, C., Mark C., Van L., Carry A., "Innovations in 3D printing: a 3D overview from optics to organs." British Journal of Ophthalmology Vol. 98, Issue 2, Pages 159-161, 2014

18. Pasinli, A., "Biyomedikal uygulamalarda kullanılan biyomalzemeler", Makine Teknolojileri Elektronik Dergisi, Vol. 4, Issue 1, Pages 25-34, 2004.

19. Kasemo, B., "Biocompatibility of titanium implants: surface science aspects", The Journal of prosthetic dentistry Vol. 49, Issue 6, Pages 832-837, 1983.

20. Naomi, M., "Mechanical properties of biomedical titanium alloys", Materials Science and Engineering: A Vol. 243, Issue 1, 231-236, 1998.

21. Brunette, Donald M., "Titanium in medicine: MaterialScience, surface science, engineering, biological responses, and medical applications”, Springer Science \& Business Media, 2012.

22. Wiria, F.E., "Printing of titanium implant prototype", Materials \& Design Vol. 3, Issue 1, Pages 101$105,2010$.

23. Dawood, A., "3D printing in dentistry", British Dental Journal Vol. 219, Issue 11, Pages 521-529, 2015.

24. Internet: 3D printing about Biomedical Engineering, http://www.mdpi.com/journal/materials/special_issues/3D_Printing_Biomedical_Engineering

25. Liu Q., Leu M.C., Schmitt S.M., "Rapid prototyping in dentistry: technology and application", Int J. Adv. Manuf. Technol. Vol. 29, Issue 1, Pages 317-335, 2006.

26. Venkatesh V., Nandini V., "Direct metal laser-sintering: a digitized metal casting technology", J. Indian Prosthodont Soc., Vol. 13, Issue 4, Pages 389-392, 2013.

27. Rengier, F., "3D printing based on imaging data: a review of medical applications." International journal of computer-assisted radiology and surgery, Vol. 5, Issue 4, Pages 335-341, 2010.

28. Kayacan, M.C., Delikanlı, Y. E., Duman, B., Özsoy, K., “Ti6Al4v toz alaşımı kullanılarak SLS ile üretilen geçişli (değişken) gözenekli numunelerin mekanik özelliklerinin incelenmesi”, Gazi Üniversitesi Mühendislik-Mimarlık Fakültesi Dergisi, Vol. 33, Sayı 1, Sayfa 127-143, 2018.

29. Wagner J., Baack B., Brown G., Kelly J., "Rapid 3-dimensional prototyping for surgical repair of the maxilla of a cial fracture: a technical note", J. Oral Maxillofac Surg., Vol. 62, Issue 5, Pages 898-901, 2004.

30. Kayacan, M. Y., Özsoy, K., Duman, B., Yilmaz, N., Kayacan, M. C., “A study on elimination of failures resulting from layering and internal stresses in Powder Bed Fusion (PBF) additive manufacturing”, Materials and Manufacturing Processes, Vol 34, Issue 13, Pages 1467-1475,2019. 
31. Cima MJ, Sachs E, Cima LG, Yoo J, Khanuja S, Borland SW., "Computer derived microstructures by 3D printing: bio-and structural materials”, Solid Free form Fabr. Symp. Proc. DTIC Document, Pages 181-190, 1994.

32. Wu B.M., Borland S.W., Giordano R.A., Cima L.G., Sachs E.M., Cima M.J., "Solid free-form fabrication of drug delivery devices", J. Control Release, Vol. 40, Issue 7, 77-87, 1996

33. Billiet T., Vandenhaute M., Schelfhout J., Van Vlierberghe S., Dubruel P., "A review of trends and limitations in hydrogel-rapid prototyping for tissue engineering", Biomaterials, Vol. 33, Issue 5, Pages 54-62, 2012.

34. Chia, H.N., Benjamin M., "Recent advances in 3D printing of biomaterials." Journal of biological engineering Vol. 9, Issue 1, Pages 4-11, 2011

35. Uzun, İ. H, and Bayındır F., "Titanium and its properties in dental applications." Journal of Atatürk University Faculty of Dentistry, Vol. 2010, Issue 3, 2010.

36. Tada, S., "Influence of implant design and bone quality on stress/strain distribution in bone around implants: a 3-dimensional finite element analysis." International Journal of Oral \& Maxillofacial Implants, Vol. 18, Issue 3, 2003.

37. Clemow, A.J.T., "Interface mechanics of porous titanium implants." Journal of Biomedical Materials Research Part A, Vol. 15, Issue 1, 73-82, 1981.

38. Kohal R.J, Att W., Baechle M., Butz F., "Ceramic abutments and ceramic oral implants" Periodontology 2000, Vol. 47, Issue 2, Pages 224-233, 2008.

39. Sundh A., Molin M., Sjögren G., "Fracture resistance of yttrium oxide partially stabilized zirconia allceramic bridges after veneering and mechanical fatigue testing”, Dent. Mater., Vol. 21, Issue 5, 47682, 2005 .

40. Lütjering G., Williams J.C., “Titanium Heidelberg”, Springer-Verlag, 2007.

41. Wiria, F.E., Shyan, J.Y.M., Lim, P.N., Wen, F.G.C., Yeo, J.F., Cao, T., "Printing of titanium implant prototype", Materials \& Design, Vol. 31, Pages 101-105, 2010.

42. Xiong, Y., Chao Q., Jian S., "Fabrication of porous titanium implants by three-dimensional printing and sintering at different temperatures." Dental materials journal, Vol. 31, Issue 5, Pages 815-820, 2018.

43. Schiefer H., Bram M., Buchkremer H.P., Stöver D., "Mechanical examinations on dental implants with porous titanium coating”, J. Mater. Sci. Mater. Med., Vol. 20, Issue 1, Pages 1763-1770, 2009.

44. El-Hajje, A., Kolos, E. C., Wang, J. K., Maleksaeedi, S., He, Z., Wiria, F. E., Ruys, A.J., "Physical and mechanical characterisation of 3D-printed porous titanium for biomedical applications", Journal of Materials Science: Materials in Medicine, Vol. 25, Issue 11, Pages 2471-2480, 2014.

45. Tunchel, S., Blay, A., Kolerman, R., Mijiritsky, E., Shibli, J.A., "3D printing/additive manufacturing single titanium dental implants: a prospective multicenter study with 3 years of follow-up", International journal of dentistry, 2016.

46. Maleksaeedi, Saeed, et al. "Toward 3D printed bioactive titanium scaffolds with bimodal pore size distribution for bone ingrowth." Procedia CIRP., Vol. 5, Issue 9, Pages 158-163, 2013. 